\title{
US spent-fuel ban leaves European research reactors out in the cold
}

Munich. A federal district court in South Carolina has confirmed an earlier ruling that the US Department of Energy (DoE) cannot require the state to accept spent fuel rods from European research reactors intended to be held in storage at the DoE's nuclear site at Savannah River.

As a result, the United States may have to renege on a previous promise to accept such spent fuel, leaving many European research reactors in crisis as their own temporary storage facilities are no longer able to meet their needs.

As part of a broad campaign to limit the spread of nuclear weapons, the United States agreed in 1978 that it would take back spent fuel rods of US origin from foreign research reactors if the countries concerned agreed to use low-enriched uranium (LEU) instead of bomb-grade highenriched uranium (HEU). This is known as the Reduced Enrichment for Research and Test Reactors (RERTR) agreement.

Nearly all those concerned agreed to make the change, despite the considerable expense involved. But in 1988, pressure from anti-nuclear groups led the United States to accepting spent fuel. Then in 1993 the Clinton administration announced a renewed commitment to anti-proliferation, requiring in particular a full environmental impact statement on the consequences of accepting foreign spent fuel.

Reactivating the agreement with foreign research reactors, however, has proved difficult. The return of spent fuel has been criticized on environmental grounds, and critics also point out that, with reprocessing stopped at Savannah River, there is no economic advantage in using interim storage.

There are now estimated to be 15,000 spent fuel rods in non-US research reactors awaiting a firm US decision. For some reactors, the issue is critical. Following an inspection of foreign facilities last summer, the DoE agreed to take back and store 409 rods from eight European reactors whose own storage facilities were already full.

The first shipment, comprising 153 rods from four European research reactors, was despatched last September. But an injunction by the South Carolina federal district court prevented the shipment from landing, the state arguing that the risks to the state's population could not be assessed until a full environmental impact statement was complete (see Nature 371, 192; 1994).

The injunction was lifted some days later when the court accepted arguments by the DoE and the Nuclear Control Institute (NCI), an independent watchdog group, and various environmental groups that the immediate risk of terrorist attack on the shipment outweighed the likely risk to the local environment.

But the court also demanded an immediate full hearing. This was completed last November, and on 26 January the judge ruled that an import ban on the remaining 256 fuel rods would be maintained, at least until the environmental impact statement is published later this year.

\section{Norway honours space physics pioneer}

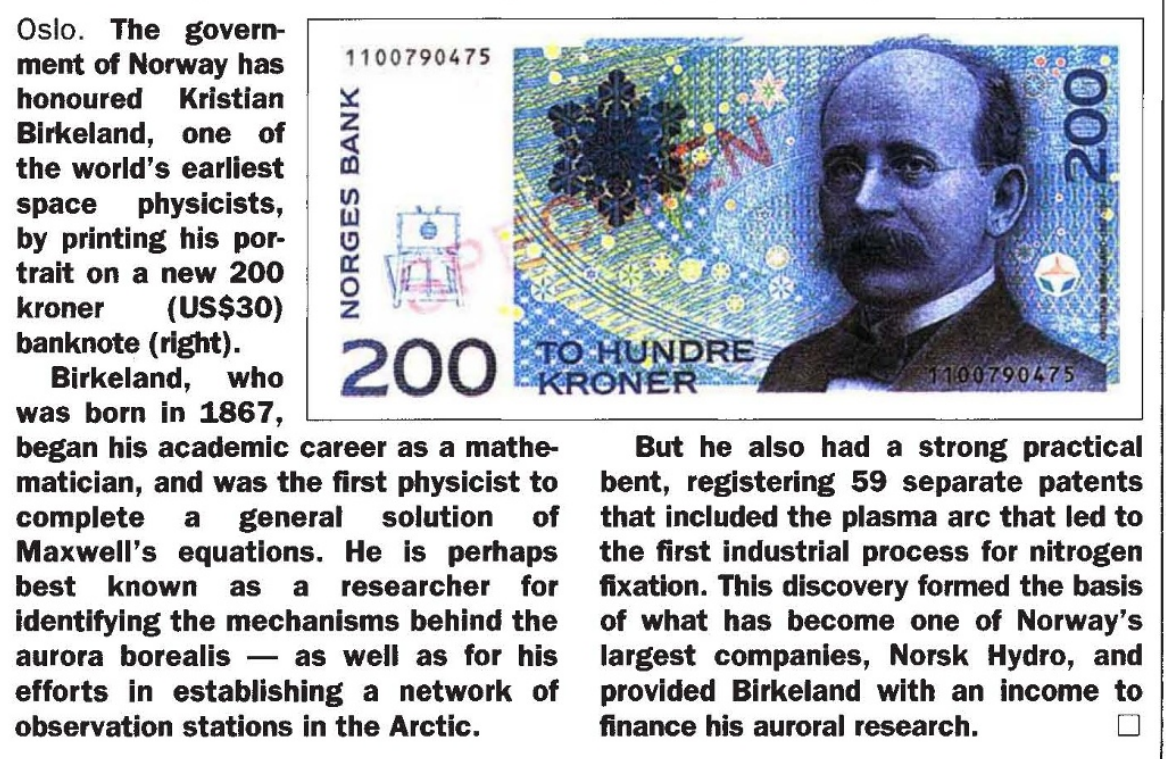

An appeal by the DoE is likely to be heard within a few weeks. The department wants the ban overturned as soon as possible so that a second shipment, carrying spent fuel from three research reactors in Germany, Greece and Switzerland, and scheduled for this spring, can go ahead.

Thomas Robertson of the Hahn Meitner Institute in Berlin, where the German reactor is located, says that if the United States is unable to find a solution, it could fall back on a second option, namely an agreement signed in 1990 with the reprocessing facility at Dounreay in Scotland.

But Robertson says that the institute would prefer to return the fuel to the United States, as the Dounreay plant handles only HEU, so reactors would have to abandon their plans to convert to LEU.

In contrast, Panagiatis Manakos, chairman of the Democritos research centre that houses Greece's research reactor, says that Greece has no alternative available. "We hope, and are optimistic, that the United States will honour its long-standing commitments, which have been the basis of our planning for our reactor," he says. The Greek reactor is in the process of converting to the burning of LEU.

There have been reports in the United States that some DoE officials have considered making a deal with South Carolina to persuade the state to accept the fuel rods - for example, by looking at the possibility of re-opening the reprocessing plant at Savannah River. But this has been denied by Hazel O'Leary, the energy secretary.

Some anti-proliferation campaigners are using the recent US decision to stop construction of the proposed Advanced Neutron Source (ANS) - a research facility which was to have burnt HEU - to argue against a new research reactor, the FRMII, which the Technical University of Munich plans to build at Garching, in Bavaria.

But Klaus Böning, the director of the FRMII project, says that the ANS decision was based on cost, and was not related to concern about nuclear proliferation. It has "no consequences" for FRMII, he says, which, despite vehement local opposition, has already secured funding agreements from the state of Bavaria and the federal government.

The opposition Social Democrat Party (SPD) has, however, called for the FRMII to be reassessed after the US decision. The SPD's parliamentary group has called on the federal government to reopen negotiations with Bavaria and the Technical University of Munich about halting the programme.

Alison Abbott 